\title{
OIL PRICES IN THE 1990s
}


Also from Surrey Energy Economics Centre and published by Macmillan Education

Edited by Paul Stevens

ENERGY DEMAND: Prospects and Trends

INTERNATIONAL GAS: Prospects and Trends

Edited by Peter Pearson

ENERGY POLICIES IN AN UNCERTAIN WORLD 


\title{
OIL PRICES IN THE 1990s
}

\author{
Edited by \\ David Hawdon \\ Lecturer in Economics \\ University of Surrey
}

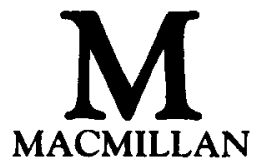


(C) David Hawdon 1989

Softcover reprint of the hardcover 1st edition 1989

All rights reserved. No reproduction, copy or transmission of this publication may be made without written permission.

No paragraph of this publication may be reproduced, copied or transmitted save with written permission or in accordance with the provisions of the Copyright Act 1956 (as amended), or under the terms of any licence permitting limited copying issued by the Copyright Licensing Agency, 33-4 Alfred Place, London WC1E 7DP.

Any person who does any unauthorised act in relation to this publication may be liable to criminal prosecution and civil claims for damages.

First published 1989

Published by THE MACMILLAN PRESS LTD

Houndmills, Basingstoke, Hampshire RG21 2XS and London

Companies and representatives

throughout the world

British Library Cataloguing in Publication Data

Oil prices in the $1990 \mathrm{~s}$.

1. Economic conditions. Effects of variation in petroleum prices

I. Hawdon, David

330.9

ISBN 978-1-349-11128-2

ISBN 978-1-349-11126-8 (eBook)

DOI 10.1007/978-1-349-11126-8 


\section{CONTENTS}

Contributors

Acknowledgements

Abbreviations

viii

ix

$\mathrm{x}$

INTRODUCTION - David Hawdon

xi

Analysis of oil prices

Oil as a commodity

Major themes of this book

References

1 OIL DEMAND IN THE 1990s - George Kowalski Introduction

Historical evolution of oil markets

Price asymmetry

Crude oil prices and economic growth

World oil demand

Oil efficiency gains

OECD oil product demand

Conclusions

2 A WORLD ENERGY OUTLOOK - Lowell C Reed 20 Primary energy consumption past and future 21 The energy GNP relationship 23

Oil demand past and forecast 23

Oil supply $\quad 27$

World reserves 27

Non-OPEC production $\quad 27$

OPEC production $\quad 30$

Crude oil price, past present and future $\quad 32$

Free world supply $\quad 35$ 
Energy demand analysis prior to 1973

Energy demand analysis, 1973-1980 42

World demand and resource modelling 43

National approaches 43

The scope for further development 45

The need for further disaggregation 45

The importance of capital stock 46

Nature and diffusion of technological change 47

Inter fuel substitution $\quad 47$

Enhanced fuel efficiency 48

Energy efficiency improvements: the track record 49

4 NON-OPEC CRUDE PRODUCTION -

Andrew Gordon $\quad 54$

History $\quad 57$

Key determinants of production prospects 58

Production prospects in the 1990s 59

5 MIDDLE EAST OIL SUPPLIES IN THE 1990s -

Paul Stevens

Introduction

Supply capability $\quad 62$

Export potential $\quad 63$

Gulf willingness to supply 69

Politics, religion and time preference $\quad 74$

Conclusion $\quad 76$

$\begin{array}{ll}\text { Notes and references } & 77\end{array}$

6 TRANSPORT COSTS AND CAPACITY

ADJUSTMENT IN THE TANKER MARKET -

David Hawdon

Factors influencing the demand for transport services 81

Changes in oil importing behaviour 81

Changes in importer route preferences 83

Decline in traditional long distance exporters 86

Changes on the supply side $\quad 86$

Tanker cost changes $\quad 89$

The freight rate model 91

Tanker scrapping and replacement 92

The analysis $\quad 95$

Possibilities for the 1990s 99

Conclusions 102

References and notes 104 
Contents

vii

7 OIL PRICES - A CONFLICT OF VIEWS

Eric Price 105

Colin Robinson 109

John Surrey 111

8 CHANGING OIL PRICE EXPECTATIONS -

David Hawdon $\quad 115$

Introduction $\quad 115$

Alternative ways of discovering oil prices $\quad 116$

Surrey Energy Centre oil price surveys 117

The 1988 survey $\quad 120$

Prices in the longer term $\quad 120$

Concluding remarks 125

$\begin{array}{ll}\text { References } & 127\end{array}$ 


\section{THE CONTRIBUTORS}

George Kowalski

Lowell C Reed

John Chesshire

Andrew Gordon

Paul Stevens

David Hawdon

Eric Price

Colin Robinson

John Surrey
Economic Adviser to the IEA and Head of the Energy Economic Analysis Division, Paris.

General Manager: Exploration \& Production International, Conoco Inc

Head, Energy Programme, Science Policy Research Unit, University of Sussex.

Manager, Energy and Analysis Branch, British Petroleum, London.

Senior Lecturer in Economics, University of Surrey

Lecturer in Economics, University of Surrey

Head of Economics and Statistics Division, Department of Energy

Professor of Economics, University of Surrey

Professorial Research Fellow, Science Policy Research Unit, University of Sussex 


\section{ACKNOWLEDGEMENTS}

The papers included in this volume are based on presentations made at the sixth annual international energy economics conference held at the University of Surrey in April 1988. Many people contributed to the smooth running of the conference but Rachael Alexander and Isobel Hildyard deserve especial mention. Liz Blakeway provided invaluable organisational supervision together with expert wordprocessing assistance in the preparation of this book for publication. Brian Secrett and Nick Conway gave many hours of graphical and computing assistance. Finally, I would like to thank the Oxford Institute of Energy Studies for providing a peaceful environment in which to complete the book. 


\section{ABBREVIATIONS}

Big Five Saudi Arabia, Iran, Iraq, Kuwait, and UAE

BF

Billion cost of bunker fuel

Bunker $\mathrm{C} \quad$ a heavy residual fuel oil used by ships

Capex

Capital expenditure

CHP

Dwt

$E$ and $P$

Combined Heat and Power generation

deadweight tons

EOR

exploration and production

FGD

enhanced oil recovery techniques

Flue Gas Desulphurisation

FT

IEA

LDC

L48

Long ton capacity utilisation of the tanker fleet (inverse measure)

International Energy Agency

Less Developed Countries

lower 48 states of US mainland excluding Alaska

LR

LVR approximately 1.016 tonnes

logarithm of Worldscale freight rate

logarithm of rates along PG/WE route

LMR

logarithm of rates along $P G / J$ route

LSR

MPG

OE logarithm of rates along Caribbean/US route miles per gallon

Oil equivalent

OECD

Organisation for Economic Cooperation and Development

PG/WE Gulf to West Europe tanker route

$\mathrm{PG} / \mathrm{J}$

Gulf to Japan tanker route

PIW

$\mathrm{R} / \mathrm{P}$

Petroleum Intelligence Weekly

reserve to production ratio

TM

UAE

logarithm of tonne-miles of oil trade

United Arab Emirates

Vlcc

very large crude carrier, that is over 250000 deadweight tons 


\title{
INTRODUCTION
}

\author{
David Hawdon
}

A few words of apology are perhaps necessary for another book on the subject of oil prices. Oil remains the single most important commodity in international trade both in volume and in value terms and its price directly affects the welfare of those involved in its production and distribution. In spite of substantial changes in relative prices since the mid-1970s oil is still the single most important form of commercial energy and its cost enters into almost every production plan and investment calculation. The relative importance of energy for the poorer sections of both industrialised and developing countries alike is sufficient to sustain a lively interest by policy makers in the price of a good which can have significant distributional consequences. Certainly it was concern of the latter sort which motivated increased governmental involvement in energy policy throughout the 1970 s and 1980 s.

Apart from these general concerns, economists have generally focused upon two major types of problems - those concerned with the efficiency of the market and those concerned with equity of income distribution. Inefficiencies in the oil market arise chiefly from the monopolistic behaviour of its chief participants so that prices do not provide a good signal of marginal costs. Thus prior to 1973 , prices were fixed by a vertically integrated group of multinational oil companies at levels which maintained growth in demand and which attracted profits to refined products rather than to crude oil. The dramatic shifts in ownership of oil sources which occurred throughout the 1970s broke up the integrated structure of the industry and moved the focus from products to crude oil prices 
now effectively controlled by OPEC. Low elasticities of oil demand and perceptions of unsustainable rates of oil resource depletion, enabled OPEC to charge monopoly prices for crude oil in the late 1970s and early 1980s. Although the subsequent recession and the expansion of non-OPEC supplies ushered in a period of lower prices, the ability of the major producer grouping to raise prices above competitive levels is responsible for the partial recovery of oil prices in 1987 and through to 1988.

One important source of inefficiency in the oil market is the lack of a full set of markets to take account of future price expectations. Not until the early 1980 s did futures markets of any sort develop and even today such markets cover only a small proportion of traded crudes and products. Not only are they limited in scope they are restricted in time horizon. The maximum forward period over which futures market trading is possible is around 12 months so that these markets are unable to convey pricing information needed for longer term investment decision making. Transactions costs remain high in certain markets for example in the Brent forward market where minimum traded quantities are relatively large. Thus the market may not be expected to function efficiently in equating marginal rates of transformation for producers and marginal rates of substitution for consumers through time.

Secondly, efficient markets require well-informed participants for the achievement of price equilibria. However, the asymmetry in information between producer governments, oil companies (especially in regard to new field development projects) and consumers, militates against the establishment of equilibrium in the oil market.

A further set of inefficiencies arises within consumer countries (which include oil producing countries) where different prices face buyers and sellers. Following the oil price shocks of the 1970s, many consumer countries raised taxes on petroleum product imports to encourage conservation and fuel substitution. These taxes have tended to remain even while the prices of oil and gas have fallen, in order to protect the investments made at the time. To the extent that consumer prices do not reflect producer prices, resource use is non optimal. Where governments have intervened to allocate oil by rationing or prohibition of certain uses for example oil or gas in power stations, distortions have been heightened. 
The second aspect of pricing with which economists have been concerned - namely equity effects - arises from the tendency for energy to occupy a more important role in the expenditure plans of poorer families in all communities. This is reflected in the relatively large amount of assistance provided by international bodies which was designed to facilitate substitution away from imported oil. Often conflict between efficiency and equity objectives have emerged as for example in efforts to ensure that domestic prices come to correspond to border or world traded prices. The course of oil prices is important in maintaining the economic and political stability of many societies.

\section{ANALYSIS OF OIL PRICES}

The history of the economic analysis of oil markets shows a swing from resource depletion and cartel based models to the modelling of oil as a commodity. Until around 1982, the academic literature rate was dominated by the former type of models. They drew upon Hotelling's earlier insight (Hotelling, 1931) that a wealth maximising producer would, in dealing with a non renewable resource like oil, produce up to the point where marginal revenue equalled the sum of marginal production cost and the user cost that is the cost of using the resource today and thereby foregoing tomorrow's profit. Where future profits are discounted, user costs must rise by the producer's rate of discount to maintain equilibrium. Under perfect competition price is equated to marginal revenue so that prices must rise through time with non-falling production costs: under monopoly only marginal revenue, which is less than price, must rise and a different, but nevertheless still rising, price path is required. In either case user costs are based on expectations of future supply and demand conditions, so anticipated developments in the oil markets could exercise a throw back effect on current prices.

Cartel theories, based on the wealth maximisation hypothesis, assumed that the dominant producer within OPEC would act as swing producer to maintain overall production levels at those which would maximise profits for the group. Unfortunately the explicit renunciation of such a role by Saudi Arabia in 1986 rendered such theories implausible. Other models of a nonmaximising type, for example the backward bending supply 
model, tried to explain instability in prices by asserting that OPEC would cut output once revenue targets had been reached (hence raising prices) and only expand output to achieve targets (thus forcing prices down). Such models provided an explanation for sudden shifts in prices but did not suggest an equilibrating mechanism. In addition they were somewhat unsatisfactory in their behavioural assumptions.

The price collapse of the mid-1980s revealed the weakness of the models. The cartel model predicted that OPEC would further restrict output in order to keep prices high and to satisfy the aspirations of each member state. However, the falls in oil demand precipitated a scramble for market share, and production by Saudi Arabia and others expanded substantially in 1986. This in itself was incompatible with model predictions. Neither could the eventual stabilisation of the market in 1987 and 1988 have been deduced from the target revenue model according to which producers continue expanding output to gain revenue in a falling market. The growth of non-OPEC supplies, coupled with the low responsiveness of oil demand to lower prices post-1986, has further weakened the perception of OPEC as an effective cartel.

\section{OIL AS A COMMODITY}

To some extent the failure of the wealth maximising models to predict price movements in the 1980 s was due to a significant change in the nature of oil trading. The breakdown of the integrated oil market, changes of ownership of oil production and the development of new oil provinces created ideal conditions for the development of commodity type trading in oil. Variation in supply, demand, stocks and price levels all increased substantially in this period and encouraged the entry of financial institutions and speculators into the market. The abandonment of term contracts resulted in much greater reliance upon the spot crude market. Then the advent of futures markets enabled at least moderately short-term trading to be protected from some of the market risk which in earlier days had been accommodated by long term contracts.

Empirical work embodying these changes in market conditions has been rather limited. Verleger's model (Verleger, 1982) of official crude oil prices as determined by movements in spot oil product prices showed that even in the period 1975 
to 1980 official prices had tended to follow market conditions. He suggested that consumer governments could prevent swings in oil prices by promoting 'calm and orderly' spot markets. Subsequent work on spot markets has concentrated on their efficiency rather than on the price determination process. Of interest is the work of Bopp and Sitzer (Bopp and Sitzer, 1988) who incorporate features of commodity type models in a model of the distillate fuel oil price. They allow explicitly for the cost of stockholding and use the futures rather than the lagged prices as a way of assessing the impact of changing expectations on present prices. This is a promising approach which could well be applied to the crude oil price.

The practical difficulties of modelling the price of oil have given rise to a number of ad hoc forecasting methods. One example is the price reaction function incorporated in the EIA model (Energy Information Agency, 1985) which represents OPEC behaviour as an attempt to achieve optimal capacity utilisation by raising prices when capacity is tight and lowering prices at other times. This approach, however, failed to anticipate the 1986 price fall which occurred as a direct result of an expansion of OPEC output. More recent attempts to model OPEC overall utility as a function of market share and export revenue may help to define limiting values which trigger action on output levels. However, the evidence suggests little more than that shares and revenues tend to circle within rather wide ranges and give little clue as to the future direction of prices.

\section{MAJOR THEMES OF THIS BOOK}

This book rather than focusing on models seeks to provide an informed framework for understanding the trends and processes which will affect prices in the next decade. It begins with a discussion by Kowalski of the likely development of world oil demand where price responses are acknowledged to be asymmetric depending upon whether or not prices rise or fall. Price rises are shown, on the basis of analysis carried out at the IEA, to depress demand more than corresponding price falls would increase it. This forms the basis of two scenario exercises designed to investigate the world oil market under conditions either of constant or of rising prices.

So long as the large oil companies remain as major operators in the world oil market, their perceptions of future 
developments will influence decisions on exploration and investment in production, refining and marketing which will impact on prices in the long term. Reed, in discussing Conoco's world energy outlook, makes the important point that the margin for error in a given assumption is of ten small in relation to the uncertainty it implies for the future. Small changes in either demand or supply can cause disproportionate movements in price. For the future, uncertainty surrounds the impact of lower oil prices on conservation and energy efficiency, government taxation policies and economic growth prospects. On the supply side some estimates are made of the cost of developing reserves and their vulnerability to price changes.

There can be little doubt of the significant contribution of technology to the reduction of unit energy requirements in all sectors of energy consumption. And yet this has generally received much less emphasis than supply availability in the meeting of energy demands. Chesshire finds part of the reason for this situation in the lack of emphasis given to demand research by both private companies and governments. After analysing developments in demand forecasting from the early 1970 s, he urges economists to pay more attention to the literature on technical change and the implications for energy demand of the widespread diffusion of electronics, telecommunications and biotechnology. The slow turnover rate of energy-burning equipment will, however, mean that adoption of radically new technologies will take place only over a lengthy time period.

Turning to oil supplies, Stevens presents an assessment of likely developments in the Middle East region, dependence on which is set to increase as non-OPEC supplies are depleted. Distinguishing between ability and willingness to supply, he deals successively with reserves, ability to produce, and to export. Neither the growth in domestic demands nor the threat of trade route disruption are likely to present more than temporary disturbances and he sees no physical limitation on crude oil supplies until well into the next century. As to the willingness to supply he argues that the expenditure needs of the major producers will ensure oil availability. There will, however, be pressure to keep prices in the \$15-20 region throughout the 1990s.

The growth of non-OPEC supplies is discussed by Gordon. He distinguishes three main components of this growth - major new provinces, reversal of trends in US production and 
production from many smaller sources. These changes were all preceded by reserve discoveries, and recent experience here indicates little grounds for confidence in future supply expansion. Although overall production levels will be maintained in the short run a process of decline is expected under a range of price assumptions beginning in the early to mid-1990s.

Fulfilling an important role in the matching of supplies to demands for oil is transport and an analysis of transport costs along various routes is provided by Hawdon. The short-run cost of transport services is seen to vary with the balance of fleet availability and requirements as well as with fuel and other operating costs. During the 1990 s the economics of maintaining tanker capacity created in boom times more than 15 years ago are likely to be increasingly scrutinised. A model of the scrap/retain decision is presented which indicates pressures which are likely to shape the fleet size and structure and hence future levels of transport costs. It is shown that under a wide variety of circumstances freight rates are likely to rise throughout the 1990s even in the vlcc market.

The book concludes with two chapters dealing directly with anticipated oil prices. The first of these is a collection of diverse views of potential outturns which reflect the continuing climate of uncertainty in this area. In the second an assessment of price expectations surveys is made. Details of a survey of opinions of energy economists taken in 1988 are contrasted with those of 1984,1986 and 1987 . What emerges is a persistent tendency to see prices rising in the medium term (up to 5 years ahead) although accompanied by a low level of confidence in any one view. 


\section{REFERENCES}

Bopp A E and Sitzer S, 1988, "On the "Efficiency" of Futures Markets: another view', Energy Economics, Volume 10, No 3, July.

Energy Information Administration, 1985, The Oil Market Simulation Model: Model Documentation Report, US Department of Energy, Washington, DC, May.

Hotelling, H, 1931, 'The Economics of Exhaustible Resources', Journal of Political Economy Vol 39, pp 137-175, April.

Verleger, P K, 1982, 'The Determinants of Official OPEC Prices', The Review of Economics and Statistics, Volume LXIV, No 2, May. 